\title{
The impact of buffer zone size and management on illegal extraction, park protection and enforcement
}

Article

Accepted Version

Robinson, E., Albers, H. J. and Busby, G. M. (2013) The impact of buffer zone size and management on illegal extraction, park protection and enforcement. Ecological Economics, 92. pp. 96-103. ISSN 0921-8009 doi: https://doi.org/10.1016/j.ecolecon.2012.06.019 Available at https://centaur.reading.ac.uk/28485/

It is advisable to refer to the publisher's version if you intend to cite from the work. See Guidance on citing.

To link to this article DOI: http://dx.doi.org/10.1016/j.ecolecon.2012.06.019

Publisher: Elsevier

All outputs in CentAUR are protected by Intellectual Property Rights law, including copyright law. Copyright and IPR is retained by the creators or other copyright holders. Terms and conditions for use of this material are defined in the End User Agreement.

www.reading.ac.uk/centaur 
Central Archive at the University of Reading

Reading's research outputs online 
The Impact of Buffer Zone Size and Management on Illegal Extraction, Park Protection, and Enforcement

Elizabeth J Z Robinson $^{\text {a,d,e }}$, Heidi J Albers ${ }^{\text {b,e }}$, and Gwenlyn M Busby

${ }^{\text {a }}$ Reader in Environmental Economics

School of Agriculture, Policy, and Development

University of Reading

e-mail:e.j.robinson@reading.ac.uk

${ }^{\mathrm{b}}$ Corresponding Author

Professor, FES/Applied Economics

Oregon State University

Richardson Hall 321

Corvallis, Oregon 97331 USA

001-541-737-1483 (telephone)

001-541-737-1393 (fax)

e-mail:jo.albers@oregonstate.edu

${ }^{\mathrm{e}}$ Senior Scientist

Department of Environmental Sciences

University of Virginia

email: gbusby@vt.edu

${ }^{\mathrm{d}}$ Associate Professor, Department of Economics, School of Business, Economics and Law, University of Gothenburg

${ }^{\mathrm{e}}$ Research Associate, Environment for Development Tanzania

University of Dar es Salaam, Tanzania 


\title{
The Impact of Buffer Zone Size and Management on Illegal Extraction, Park Protection, and Enforcement
}

\begin{abstract}
Many protected areas or parks in developing countries have buffer zones at their boundaries to achieve the dual goals of protecting park resources and providing resource benefits to neighbouring people. Despite the prevalence of these zoning policies, few behavioural models of people's buffer zone use inform the sizing and management of those zones. This paper uses a spatially explicit resource extraction model to examine the impact of buffer zone size and management on extraction by local people, both legal and illegal, and the impact of that extraction on forest quality in the park's core and buffer zone. The results demonstrate trade-offs between the level of enforcement, the size of a buffer zone, and the amount of illegal extraction in the park; and describe implications for "enrichment" of buffer zones and evaluating patterns of forest degradation.
\end{abstract}

JEL codes: Q23, Q56, K42

Key words: Protected area management; forest reserves; costly enforcement; buffer zone management; spatial economics

Acknowledgement: We gratefully acknowledge financial support from the Sidafunded Environment for Development initiative, and from FORMAS COMMONS. 


\section{Introduction}

During the last 30 years, the number of protected areas (PAs) worldwide established to protect natural systems has grown dramatically. Coinciding with that expansion, buffer zones at the boundaries of PAs have increasingly been incorporated into management plans in an attempt to serve the multiple purposes of protecting resources within the park core; providing resource benefits to local people who often must bear the burden of the PA; and desires for PAs to reduce poverty (Wells and Brandon, 1992; Naughton-Treves et al., 2005; Dudley, 2008). ${ }^{1}$ For example, UNESCO's Biosphere Reserves incorporate three zones - a core zone, a buffer zone, and a transition area - to achieve conservation, development, and logistical functions (UNESCO, 2011). Recent satellite imagery and inquiries into the effectiveness of parks find high levels of degradation in buffer zones and areas outside of parks (Bruner et al., 2001; DeFries et al., 2005; Martin and Blackburn, 2009). These observations and the absence of appropriate control sites for comparison to in-park sites highlight the need to "study land-use dynamics in areas adjacent to protected areas that are formally designated buffer zones" because they show "more intensive use in buffer zones than in areas further away from the protected area, but causal explanations for this pattern of intensive use are weak or absent" (Naughton-Treves et al., 2005).

Despite increasing recognition of the social and ecological importance of buffer zones and the lack of causal explanations for patterns of degradation, only general guidelines exist to inform decisions over the size of a buffer zone (Dixon and

\footnotetext{
1 The definition of buffer zones varies but a typical buffer zone permits local people to
} extract or grow products in a manner that does not threaten the core park areas. 
Sherman, 1990; Dudley, 2008; Albers, 2010). Those guidelines may aim specifically at one goal of buffer zones, such as creating a forested distance between habitat and agricultural plots as determined by a species' needs, or providing enough buffer zone forest to provide a subsistence level of fuelwood to neighbours. Even when buffer zone sizing and management decisions effectively address one such goal, however, little analysis of the broader impact of the buffer zone exists such as its effect on degrading and illegal activities within the core zone. Similarly, the interaction and potential trade-offs between the multiple aims of buffer zones have not been addressed in a systematic way. Albers (2010) provides a starting point for investigating the impact of buffer zone size on conservation and rural welfare outcomes by demonstrating theoretically that the width of a buffer zone and the level of enforcement in the core zone can be substitutes, yet this trade-off is not addressed in the literature nor policy. With buffer zones meant to support the general mission of parks including protecting core resources while limiting the burden of parks on local people, a framework that places buffer zones within a broader context provides a basis for buffer zone policy as part of conservation policy.

Building off a series of spatially explicit resource extraction and enforcement models (Robinson et al., 2002; Albers, 2010; and Robinson et al., 2011), this paper examines the impact of buffer zone size, enforcement levels, and enrichment activities on local people's legal and illegal extraction decisions and the resulting levels of park protection and park-people conflict. Following the seminal Becker (1968) framework, our framework incorporates incomplete enforcement, in contrast to complete (Robinson et al. 2011) or no (Robinson et al., 2002, 2008) enforcement. Including incomplete enforcement implies that the model allows for illegal extraction activities in the protected core zone, a central feature of many protected areas. The model is 
game theoretic in nature, and because it accommodates settings where there are areas with both enforcement and illegal resource extraction, it allows us to explore the possibility of conflict between villagers and park managers (unlike Robinson et al., 2011). In this paper, we focus solely on spatial interactions to explore how management decisions influence the spatial extraction decisions of local people but generalize from the specific geometry of the protected area explored in Albers (2010). Analysis of the spatial extraction model and trade-offs informs buffer zone sizing and management decisions, rather than relying on vague statements about meeting people's needs, creating goodwill, or guessing at appropriate widths (Dixon and Sherman, 1990; Shafer, 1999). We demonstrate that, for example, once incomplete enforcement is a possibility, intermediate sized protected areas surrounded by a buffer zone may result in both a larger pristine area of forest and reduced conflict between villagers and patrollers than a larger protected area with a small or no buffer zone.

Buffer zone management tools include the choice of buffer zone width and enforcement of access restrictions at the buffer zone-park boundary. ${ }^{2}$ Empirical studies demonstrate that distance to resources creates an important cost in the resource extraction production function (Skonhoft and Solstad, 1996; MacDonald et al., 1998; Kohlin and Parks, 2001). Buffer zones create a distance between local villagers living at the buffer zone boundary and the park resources, and that distance enters villagers' decisions about extraction locations. Higher levels of enforcement discourage extraction within the park, but parks rarely have sufficient budgets to deter all degrading activities within their boundaries (Bruner et al., 2001; Figueroa and

2 In practice, the size and shape of the buffer zone depends on site-specific characteristics including socioeconomic conditions and threats to the core areas but most buffer zones are contiguous with the core zone. 
Sanchez-Cordero, 2008). With low budgets, incomplete enforcement leads to illegal extraction within the park boundaries.

In addition to choices over buffer zone width and enforcement levels, management decisions can include "enrichment" of the buffer zone to increase the benefits it provides to local people (e.g. Hjortso et al., 2006) or to reduce illegal extraction within protected areas. For example, Straede and Treue's (2006) analysis of Royal Chitwan National Park in Nepal suggests that illegal activities in the park result from higher resource abundance there and that those activities would not be necessary following enrichment activities in the buffer zone. Because villagers consider buffer zone width, the quality of resources within the buffer zone and core zones, and enforcement in their extraction decisions, effective park management must also consider width, enrichment, and enforcement decisions jointly.

This paper's next section 2 describes a spatial extraction model of a nontimber forest product - defined by the Center for International Forestry Research (CIFOR) as "...any product or service other than timber that is produced in forests" (CIFOR, 2011) - that incorporates a villager's response to resource density within the buffer zone and the protected area, and the forest manager's enforcement. Section 3 uses the model to determine the impact of buffer zone width, enforcement, and enrichment activities on extraction, benefits to locals, and degrading activities in the core area. The final section discusses the implications of these results for park and buffer zone siting, sizing, and management decisions and for evaluating park effectiveness.

\section{The model}


In our model we envisage a single-dimensional expanse of forest of width $X_{F}$. A large number of villagers live adjacent to this forest throughout which a valuable resource is evenly distributed. In the context of Tanzania and several other African countries where forest reforms have been introduced, this forest could be a previously designated government forest that had seen little protection and was now being placed under a new forest management regime such as joint forest management (Persha and Blomley, 2009). In such a situation the extraction of forest resources could be banned in most of the forest but, as we have found in Tanzania's Amani Nature Reserve, the forest manager might allocate some area of the forest to a buffer zone from which resource collection is allowed (Robinson et al., 2011). In our model, the forest manager (or forest management team) chooses how much of the forest to allocate as the protected inner core where resource collection is not permitted (width $X_{P A}$ ), and how much to allocate as a buffer zone (width $X_{B}$ ) from which villagers can legally collect resources $\left(X_{B}=X_{F}-X_{P A}\right)$. As such, the forest manager behaves in the same way as the forest manager in Robinson et al. (2011). However, whereas Robinson et al. (2011) assumes perfect enforcement of a protected zone so that extraction only occurs in a buffer zone, in contrast, in this paper we model a more commonly found scenario in which the forest manager cannot under all situations completely deter extraction from the core zone. We therefore allow for the possibility of NTFP extraction occurring in the protected zone, and villagers being caught in this zone and punished. By extending the model to incorporate imperfect enforcement and illegal activities, the model presented and analyzed here identifies the forest manager's trade-offs between buffer zone size, enforcement, and the degree of illegal extraction and degradation within the core zone; trade-offs that models in earlier papers cannot accommodate. By including illegal extraction this paper therefore takes a significant 
step towards a more realistic setting that more completely represents some of the manager's trade-offs, and identifies areas of potential conflict between villagers and managers. Because the goals in establishing buffer zones include protecting the inner core, providing benefits to local people, and reducing people-park conflict, the model analyzed here provides a more appropriate platform for considering buffer zone sizing decisions than any of our previous models.

\subsection{The forest manager's choice}

In practice, a forest manager's objective function can include a variety of factors such as the amount of pristine (or no-extraction) forest, the biomass of the landscape, and the welfare of individuals (see Robinson et al., 2011, for a comparison across forest manager objective functions in a similar context but where the core zone is perfectly enforced and all extraction is in the buffer zone). Because the shape and characteristics of the forest manager's objective function can mask the reaction of villagers to a policy and the resulting impact on forest characteristics and rural welfare we do not make any explicit assumptions about our forest manager's objective function. Rather we parametrically vary the size of the core zone that the forest manager attempts to protect and determine the impact of this size on returns to the villager, total degradation both in the protected core and the buffer zone, and the size of forest that is actually fully protected. We undertake sensitivity analysis for a wide range of enforcement budget levels and policy combinations, which allows us to focus on the villagers' reaction to the forest manager's choice. In summary, the forest manager's choice variables are the width of the protected core and the number of rangers, $N$, who patrol at the boundary between the core and the buffer zone, such that the probability of the villager being caught leaving the core is $p(N)$, where $p^{\prime}(N)>0$ and $p^{\prime \prime}(N)<0$. 


\subsection{A villager's optimisation}

Demand for forest products by nearby villagers in low-income countries depends on many factors. For example, demand for fuelwood is relatively inelastic and many villagers collect the firewood that they require from the forest rather than relying on markets. In contrast, forest resources such as weaving materials and honey are often important sources of cash income and villagers are likely to make a marginal decision over how much to collect that is influenced by their opportunity cost of labour and market prices and access (Mahapatra et al., 2005; Adhikari et al., 2007; Lopez-Feldman and Wilen, 2008; Robinson and Kajembe, 2009). In this model, villagers maximize their expected returns to collecting forest resources that are sold in the nearby market, given some positive opportunity cost of their labour. Villagers face uncertainty because choosing to collect forest resources in the protected core zone bears the risk of being caught and punished.

The villager's optimization can therefore be considered in the following way. A risk-neutral villager chooses how far into the forest to go, $X$, and how intensively to extract forest resources, to maximize her expected returns from the sale of the NTFPs. Following Robinson et al. (2008), the villager has two choice variables: the distance she goes into the forest, $X$; and $w(x)$, the time spent collecting forest resources per unit distance across that width. $w(x)$ translates into a harvest intensity $h(x)$ at a distance $x$ from the village, which is a function of $w(x) ; m(x)$, the resource density at that distance from the village; and $\alpha$, a parameter that takes into account extraction effectiveness. This formulation is such that the more time a villager spends per unit distance, the more she harvests, or extracts, per unit distance. 
Given our assumption of enforcement at the boundary between the core and extraction zones, the villager knows that if she chooses to collect from the core zone, there is some probability that she will be caught leaving the core zone at its boundary with the buffer zone, where enforcement patrols are located. If caught, the punishment includes confiscation of anything extracted, a fine that is proportional to the amount confiscated, and expulsion from the forest without being allowed to collect from the buffer zone. This standard punishment regime derives from field observations and similar punishment structures in the literature. Villagers can only be punished if they are caught coming out of the protected core and in possession of forest resources; the possession of forest resources alone is not an illegal act (nor is entering the exclusion zone). ${ }^{3}$ The villager knows how much enforcement effort there is and where the boundary between the buffer zone and the core zone is, but not exactly where on the boundary a patroller will be at any given time. The villager therefore goes into the forest, turns around at some distance that could be in the buffer zone or in the core, and extracts the resource as she moves back towards her home. ${ }^{4}$ If the villager does enter the core zone, she faces uncertainty as to whether or not she will be caught by the patrollers on the way out and therefore makes decisions based on the expected value of an extraction trip. Extraction is costly for villagers because they could

\footnotetext{
${ }^{3}$ Forest patrollers cannot tell whether villagers in possession of forest resources collected these resources legally from the buffer zone or illegally from the protected core but make the determination that leaving the core zone with forest products implies the illegal extraction within that zone. For example, Tanzanian forest managers make such an assumption about people exiting Ruvu North Forest Reserve unless the individual can provide documentation of the source of the fuelwood or charcoal.

${ }^{4}$ Naturally there are many ways that enforcement could be spatially allocated. For example, it could be spread throughout the width of the core, through some proportion of the core, as is found in Albers (2010), or at the boundary of the core and buffer zone as is the case in this paper. Our choice in this paper of situating enforcement at the core-buffer boundary allows us to focus on the key elements of a buffer zone/enforcement strategy and in particular the tradeoffs between the width of the core and buffer zones, enforcement, and illegal extraction from the core.
} 
allocate time to other activities, whether paid labour, on-farm labour, or working in the home. In common with much of the law enforcement literature, we solve the model as a Stackelberg interaction between the forest manager responsible for enforcement who moves first, choosing the size of the protected core, and the villagers whose choice over from where to collect forest resources responds to the forest manager's choice.

The villager's optimal distance decision fits within three possible endogenous distance scenarios: (a) "Core", she chooses to extract in the core zone as well as the buffer zone, thereby risking being caught and punished while leaving the core; (b) "Boundary", she chooses to extract in the buffer zone just up to the enforcement boundary, thereby extracting legally and not risking being caught; and (c) "Buffer", she chooses to extract within the buffer zone but not to the edge of the zone, again not undertaking any illegal extraction and not risking being caught. These three possibilities are shown schematically in Figure 1, with the villager's path under each scenario marked by a dashed line. Which scenario holds for a villager is endogenous to the model parameters including the width of the buffer and the level of enforcement chosen by the forest manager. Although the buffer zone is defined by where the enforcement boundary is located, the "extraction zone" where extraction occurs is defined by the villagers' distance decision ( $X$ in Figure 1 ). The extraction zone may therefore be bigger than, smaller than, or the same size as the buffer zone.

Setting the initial resource density in the buffer zone, $m_{B}$, and the initial resource density in the core zone, $m_{P A}$, constant over distance implies a constant extraction intensity in each zone (Robinson et al., 2002). We therefore write the 
harvest function explicitly as (where the subscript $i$ can be either $B$ for the buffer zone or $P A$ for the core zone):

$$
h_{i}=m_{i}\left(1-\frac{1}{\left(1+\alpha m_{i} w_{i}\right)}\right)
$$

The key element of the harvest function is that the more time the villager spends per unit distance in the forest, $w_{i}$, the greater the harvest, but with diminishing returns to $w_{i}$. If the villager chooses to collect from the PA and the buffer zone, the "Core" scenario, then, with $q$ as the price of the extracted forest resource, and $F$ the fine per unit of the resource if the villager is caught, the villager's expected revenues $R$ from extracting to a distance $X$ are:

$$
\begin{array}{ll}
E[R]=\quad & (1-p) q m_{B}\left(1-\frac{1}{\left(1+\alpha m_{B} w_{B}\right)}\right) X_{B} \\
& +(1-p(1+F)) q m_{P A}\left(1-\frac{1}{\left(1+\alpha m_{P A} w_{P A}\right)}\right)\left(X-X_{B}\right)
\end{array}
$$

The first term on the RHS of Equation 2 gives the expected returns to extraction in the buffer zone (the villager can only extract in the buffer zone if she has not been caught and evicted from the core zone). The second term gives the expected returns to extraction in the core zone (if she is caught she gets no revenue and pays a fine proportional to the amount she has collected illegally). The villager's choice variables are therefore $X, w_{P A}$, and $w_{B}$, where $w_{P A}$ is the rate of traversing though the PA, and $w_{B}$ through the buffer zone.

The villager's time costs $C$ are a non-linear function of the total time spent in the forest, $T ; k$, a simple scaling parameter; and $\gamma$, which reflects the labour market conditions. When $\gamma=1$, the villagers' opportunity cost of time is constant, which 
implies a perfectly functioning labour market with a constant market wage as the opportunity cost (Robinson et al, 2011). The low-income rural areas that our paper considers rarely contain such perfect labour markets, making such an implicit assumption unrealistic. Therefore in this model we set $\gamma>1$ implying an incomplete labour market. For example, such a situation would be relevant to villagers allocating some fixed quantity of labour between farming with diminishing returns to labour or collecting from the forest (Robinson et al, 2011): ${ }^{5}$

$$
C=k\left(\frac{1}{\gamma}(T+1)^{\gamma}-\frac{1}{\gamma}\right)
$$

$T$ depends on which endogenous distance decision scenario holds for the villager"s turn-around distance. For example, in the "Core" scenario, if the villager goes into the core zone and is not caught at the enforcement boundary, $T$ comprises walking into the forest and back, $2 v X$, where $\mathrm{v}$ is the time it takes the villager to walk a unit distance through the forest; extracting in the core, $w_{P A}\left(X-X_{B}\right)$; and extracting in the buffer zone, $w_{B} X_{B}$. If she is caught, her time costs differ because she must leave the core where she is caught at the boundary and cannot extract in the buffer zone. Her total expected time costs can therefore be written as:

$$
\begin{aligned}
E[C] & =p k\left(\frac{1}{\gamma}\left(2 v\left(X+X_{B}\right)+w_{P A}\left(X-X_{B}\right)+1\right)^{\gamma}-\frac{1}{\gamma}\right) \\
& +(1-p) k\left(\frac{1}{\gamma}\left(2 v X+w_{P A}\left(X-X_{B}\right)+w_{B} X_{B}+1\right)^{\gamma}-\frac{1}{\gamma}\right)
\end{aligned}
$$

$5 \quad$ From a modeling perspective, if $\gamma=1$, then when we differentiate the expected revenues with respect to there is no interior solution for $X_{B}$ because it drops out of the FOC. The resulting solution is to extract throughout the entire forest or not at all. 
With $E[V]=E[R]-E[C]$, conceptually the optimal harvest intensity in the buffer zone and core and the distance into the core that the villager extracts for the "Core" scenario would be determined by taking the first order conditions with respect to $X, w_{P A}$, and $w_{B}$ and solving simultaneously. However, analytical solutions to the simultaneous equations cannot be determined for any but the simplest formulations.

If the villager turns around just before the boundary of the core zone, "Boundary" scenario, $X=X_{B}$ and $p=0$ and the villager has only one choice variable, $w_{B}$. The villager's optimization becomes:

$$
\max _{w_{B}}\left[m_{B}\left(1-\frac{1}{\left(1+\alpha m_{B} w_{B}\right)}\right) X_{B}-k\left(\frac{1}{\gamma}\left(2 v X_{B}+w_{B}+1\right)^{\gamma}-\frac{1}{\gamma}\right)\right]
$$

For the "Buffer" scenario, there are two choice variables, ${ }^{w_{B}}$ and $X$ $\left(X<X_{B}\right)$. In this scenario villagers choose not to go as far as the boundary of the buffer and core zones and so are not constrained by the buffer zone. In this case the optimization is written:

$$
\max _{w_{B} X}\left[m_{B}\left(1-\frac{1}{\left(1+\alpha m_{B} w_{B}\right)}\right) X-k\left(\frac{1}{\gamma}\left(2 v X+w_{B}+1\right)^{\gamma}-\frac{1}{\gamma}\right)\right], X<X_{B}
$$

This scenario, explored in detail in Robinson et al. (2002), is the least interesting for this paper because the buffer zone is not a binding constraint for the villagers' extraction distance decision.

Whether or not a villager chooses to enter the core zone is determined by comparing the returns to each of the three scenarios for a particular probability of being caught and location of the buffer-core boundary. 


\section{Parameterization and results}

This model determines where villagers extract and the intensity of this extraction as a function of two buffer zone characteristics that the forest manager controls: the width of the buffer zone; and the probability of detection/enforcement of extraction beyond that zone. In this section we also address a third possible choice variable for the forest manager, enrichment of a degraded buffer zone to increase forest density there, proxied by varying $m_{B}$. Because the analytical model cannot fully depict all the characteristics of interest, we use optimization simulation analysis to solve the model for a wide range of parameter values and map the pattern of extraction resulting from changes in buffer zone width, enforcement levels, and relative degradation of the buffer zone. This information, paired with ecological data and rural welfare goals, can inform manager's decisions about buffer zone size and management.

\subsection{Parameter values}

In this paper we develop a general model rather than a particular case study. We therefore choose parameter values that permit exploration of a wide range of possible scenarios and allow comparisons of decisions amongst scenarios. The parameter values themselves do not therefore represent a particular situation. The representative villager makes her extraction distance and intensity decision in a 10 unit wide forest (see Robinson, et al., 2002, for the impact of heterogeneous villager decisions on forest density patterns). ${ }^{6}$ With an initial condition of homogeneous resource density across the landscape, we choose the baseline simulation's parameters to ensure that the villager when facing no enforcement chooses an internal distance

\footnotetext{
${ }^{6}$ Individual villagers travel perpendicularly into the forest, making a one-dimensional distance decision. Summing the individual villagers who are located along the forest boundary creates a two dimensional pattern of extraction and forest degradation.
} 
solution, that is, less than the full 10 units of the forest. When we set $v=0.8 ; \alpha=0.3$; $p=0.1 ; m=8 ; ; k=3 ; \gamma=1.4, q=4.6 ;$ and $F=0$, this distance is 8.2 units, or 82 percent of the forest width. Because distance is costly for the villagers, the remaining 1.8 units of forest are protected by distance alone (Robinson et al., 2002; Albers 2010). We choose a zero value for the fine because, as can be seen explicitly in Equation 2, the value of the fine augments the probability of being caught, making $p$ and $F$ substitutes. Thus, parametrically increasing $F$ has a similar impact to parametrically increasing $p$. In the approach here, we first impose a constant level of enforcement (implying a fixed budget for the forest manager) and then look for relationships either between the level of enforcement and the width of the buffer zone or the relative quality of resource in the buffer and protected zones.

\subsection{Impact of buffer zone width on forest extraction decisions}

Because larger buffer zones provide more legal benefits to villagers, practitioners may, at first blush, expect that larger buffer zones will reduce extraction in the core zone. To investigate the impact of impact of the buffer zone width on villager decisions, we set the enforcement level, $p=0.1$. We then parametrically vary the buffer zone width and determine the villagers' optimal extraction distance as a function of that width. The results include the width of the extraction zone, the total amount harvested, and the expected returns to the villagers at each possible buffer zone width (Figure 2).

\subsubsection{Do wider buffer zones reduce extraction in the core?}

At relatively small buffer zone sizes, up to 3.2 units wide, the villager chooses to extract in both the buffer zone and the core zone despite the risk of detection within the core zone (scenario a in Figure 1 and Figure 2, where the extraction zone width is 
above the 45 degree line). For example, if the buffer zone is two units wide, the villager extracts over 6.2 units, which includes extracting 4.2 units into the core protected area (Figure 2 "Core" scenario). Varying the size of the buffer zone between zero and 3.2 units does not change the distance the villager goes into the forest. However, the villager's harvest intensity in the protected zone varies slightly depending on the width of the protected zone because the latter affects how many of the distance units are within the protected zone and therefore risky, and how many are in the buffer zone and therefore not risky.

For intermediate sizes of the buffer zone ( 3.2 to 8.2 units wide), the villager chooses to turn around at the boundary of the core zone rather than risk extraction in the core ("Boundary" scenario). The greater legal access to forest resources due to a wider buffer zone combined with the level of enforcement at the boundary results in villagers extracting from the full width of the buffer zone but not beyond. The buffer zone width interacts with the enforcement level and, at these intermediate buffer zone sizes, the villager prefers not to risk losing the entire amount collected by entering the core (scenario $b$ in Figure 1). In these circumstances, the buffer zone and extraction zone coincide, the buffer zone binds, and villagers undertake no illegal extraction. ${ }^{7}$ The resources in the core zone are thus protected by combination of the wider buffer zone and enforcement. For larger buffer zones (>8.2 units) the buffer zone no longer binds and, no matter how large the buffer zone is, villagers choose to go 8.2 units into the buffer zone, turning around before the official boundary.

\footnotetext{
${ }^{7}$ If the buffer zone is larger than 8.2 units, the enforcement at the PA boundary is no longer binding (and is therefore unnecessary). The villager is unconstrained, choosing to extract only up to a distance of 8.2 units from her house despite the wider formal buffer zone.
} 
Perhaps counter-intuitively, increasing the width of the buffer zone decreases the size of the extraction zone at only one point: the point at which the villager shifts between interior distance decisions with illegal extraction ("Core" scenario) to constrained or "corner" distance decisions with only legal extraction up to the boundary of the buffer zone ("Boundary" scenario). What size buffer zone leads to this endogenous scenario shift depends on the returns to extraction and the risk of being caught extracting illegally. The width of the buffer zone informs the marginal distance decision only when that width is binding, which occurs only in the distance decision scenario of extracting up to the buffer zone boundary.

Our model shows that an intermediate rather than small sized buffer zone deters illegal extraction. Such intermediate-sized buffer zones bring an added benefit of reducing head-to-head conflict between villagers and park guards. When villagers extract illegally a combative relationship between villagers and forest managers can arise and when villagers are detected during illegal extraction, direct conflict between guards and villagers can ensue (Robinson et al., 2010). This conflict might be considered in the enforcement cost function but it might also be part of a manager's objective function: to minimize park-villager conflict. Although villagers may still harbour negative feelings towards forest managers in a setting with an intermediate to large buffer zone, no instances of direct conflict arise in our model because the villagers choose to extract only legally.

\subsubsection{Do wider buffer zones promote forest quality?}

Different types of forests create ecological benefits in various ways. If NTFP extraction degrades the forest in ways that alter the provisions of benefits or services, the amount of NTFP extraction may provide one indicator of the forest's quality or the forest's ability to generate those benefits. For example, a park's ecological 
benefits may derive only from forests without extraction that are relatively pristine or, alternatively, from maximizing the forest biomass within the buffer and core zones, among other possible processes (Robinson et al., 2011). ${ }^{8}$ For a particular level of enforcement, the results in Figure 2 demonstrate the impact of the choice of a buffer zone on these two measures of "forest quality". As the inverse of the amount of forest biomass remaining, total amount of forest biomass harvested follows the extraction distance decision, as seen by the "total harvest" line on Figure 2. At the baseline parameter values, the width of the buffer zone that maximizes either of the forest quality measures - pristine width or total remaining biomass - occurs at buffer zone width of 3.2. That buffer zone width leads to a total biomass of 62.6 units (out of a no-extraction total of 80 units) and a 6.8 unit wide core zone. At smaller buffer zones, the pristine area is smaller (around 3.8 units) and the total remaining biomass smaller (around 47 units) than at the intermediate sized buffer zone width. Similarly, large buffer zone widths lead to smaller pristine areas and lower biomass remaining. The finding that an intermediate sized buffer zone leads to higher forest quality (by these two measures) than very small or very large buffer zones comes from the villagers' spatial extraction decisions as a function of both distance and enforcement costs. Only when the buffer zone's width causes the villager to switch from extracting within the core zone illegally to turning around at the enforced boundary does a decision to widen the buffer zone lead to large changes in forest quality, for a given level of enforcement.

\subsubsection{Do wider buffer zones benefit villagers?}

Not surprisingly, the larger the buffer zone, the greater the expected returns to villagers from collecting forest resources. However, this relationship contains a

\footnotetext{
${ }^{8}$ Robinson et al. (2011) considers four different forest manager objective functions and four different damage functions that describe the impact of extraction on forest quality.
} 
distinct non-linearity. With small buffer zones and villagers extracting illegally in the core zone, increasing the buffer zone has a small impact on their expected returns. When the buffer zone boundary becomes a binding constraint at a width of 3.2 units, increasing the width of the buffer zone further has a greater marginal impact on villagers' returns to extracting as they increase their extraction distance to equal the buffer zone width. Naturally, when the buffer zone width is greater than 8.2 units and no longer binding, its width does not affect villager returns to extraction. Attempts to manipulate buffer zone widths to benefit villagers will produce more significant effects if the buffer zone width binds villagers, inducing only legal extraction.

\subsection{Enforcement needed to deter villagers from extraction in the core zone}

Forest managers typically face budget constraints that limit the probability of detection that they can impose, which makes incomplete enforcement and illegal extraction in the core common. We reflected such a situation in the analysis above, where we maintained a constant level of enforcement expenditure and varied the width of the buffer zone. In this section in contrast, we vary the probability of detection and enforcement at the buffer-core boundary. From the villager's perspective, a probability of detection exists that induces them to not extract in the core zone. Because of the distance costs in the extraction production function, that probability varies with the width of the buffer zone; it takes a lower probability of detection to deter illegal extraction in the core if the core is farther away (Albers, 2010). Viewing the minimum probability that deters a villager from entering the core zone as a proxy for the extraction pressure on the boundary between the buffer zone and this core, we examine how pressure on the boundary changes with management decisions about buffer zone width, enforcement levels, and buffer zone enrichment activities. 


\subsubsection{Enforcement probability and buffer zone width}

Because of the distance cost, the width of the buffer zone interacts with the enforcement probability in determining the representative villager's optimal extraction distance and whether illegal extraction occurs in the core zone. In Albers (2010), due to the spatial structure of the forest, the forest manager can afford a higher level of enforcement at higher distances from the village, which leads to an optimal width for the buffer zone. Here, the enforcement costs do not vary with the location of the buffer-core boundary but the villagers' distance cost creates different pressure on the boundary depending on that boundary's location.

In Figure 3 we plot the minimum probability of being caught required to deter a villager from entering the core zone for different widths of the buffer zone, assuming homogeneous resource density. The figure demonstrates explicitly the trade-off between the width of the buffer zone and the cost of enforcement required to protect fully the core zone of the forest - the larger the buffer zone, the smaller the enforcement budget required to prevent illegal extraction in the core zone. The distance cost effectively augments the enforcement budget. Thus even without cost savings from patrolling a smaller area, as in Albers (2010), the forest manager faces lower costs of deterrence with a larger buffer zone. A forest manager can compare those cost savings with lost benefits from having a smaller core zone in determining buffer zone size.

\subsubsection{Does buffer zone "enrichment" protect the core zone?}

The analysis behind Figure 3 assumes a homogeneous resource density across the buffer and core zones. In practice, the buffer zone is likely to be more degraded 
than the core zone (Bruner et al., 2001; Figueroa and Sanchez-Cordero, 2008). ${ }^{9}$

Because the resource density enters the villagers' extraction decisions, a more degraded buffer zone changes the pressure on the boundary and the enforcement required to protect the core zone from illegal extraction. To explore this relationship, we fix the size of the buffer zone, first to a width of 3.2 units and then 2.0 units, and vary the level of degradation in the buffer zone relative to the pristine core zone (Figure 4). For example, with the same resource density in both the buffer and the core zone $\left(m_{B}=m_{P A}=8\right)$, a buffer zone of 3.2 units requires an enforcement probability of 0.10 to deter extraction from the core zone (as in Figure 3 at 3.2 units wide buffer zone and in Figure 4 at resource density $=100$ percent). But a buffer zone of width 2 requires twice the enforcement probability of 0.20 . Conversely, with a fully degraded buffer zone $\left(m_{B}=0\right)$, no enforcement is needed if the buffer zone is 3.2 units wide because, even without enforcement, villagers choose not to collect at all. This is because with complete degradation in the buffer zone the distance to reach the core zone presents too large a fixed cost to merit illegal extraction in the core as the villagers do not get any revenue from extraction in the buffer zone that would offset the distance costs of travelling through the buffer zone. In contrast, with the smaller 2-unit buffer zone fully degraded, enforcement at the boundary is still required $(p=0.17)$ to prevent villagers collecting from the core zone.

\footnotetext{
${ }^{9}$ Here we emphasize purely spatial aspects of resource extraction. Although it is out of the scope of this paper to model dynamic pathways of resource extraction, this framework's finding of extraction closer to villages corresponds to observed patterns and suggests that villagers without long-term property rights in the buffer zone will extract in patterns that lead to degraded buffer zones over time. The analysis of degraded buffer zones here can be viewed as an initial condition that derives from years of extraction. See Robinson, et al. (2011) for analysis of extraction decisions over time with resource regeneration, community management rights, and no enforcement.
} 
Figure 4 contains a distinct non-linearity in the relationship between the pressure on the boundary and the relative degradation of the buffer zone. When the buffer zone is highly degraded, relatively little enforcement effort, if any, is required to protect fully the core zone because villagers incur a fixed "distance cost" passing through the buffer zone with little extraction benefit in return. For less-degraded buffer zones, relatively more enforcement is required to prevent villagers from entering the core zone because the buffer zone's extraction benefits outweigh the distance costs and encourage longer extraction distances, thereby putting pressure on the buffer-core boundary. However, when the resource density in the buffer zone is about 60 percent greater than that of the pristine forest, further increases in resource density reduce the enforcement effort required to deter villagers from going into the PA. Because punishment for illegal extraction includes lost access to the buffer zone, when the buffer zone resource density is relatively high, villagers have more at risk when extracting illegally in the core zone and instead focus their extraction in the buffer zone.

Managers often seek to "enrich" degraded buffer zones to protect the core zone (Straede and Treue, 2006; Hjortso et al., 2006). Our results, however, demonstrate that whether such resource-density increasing activities lead to more or less illegal extraction in the core zone depends on the level of enrichment, the width of the buffer zone, and the enforcement probability. When the buffer zone is very degraded, enhancing the resource in the buffer zone may put the core zone at risk if the enforcement effort is not increased in parallel. In effect, degradation of the buffer zone increases the fixed costs of getting to the core zone and therefore distance costs plus degradation in the buffer zone protect the core zone. However, if the buffer zone is less degraded, enhancing the buffer zone further may reduce pressure on the 
boundary thereby reducing enforcement costs and/or illegal extraction. A priori it is not possible to predict the impact of a policy intervention that improves resource quality within the buffer zone, but these results demonstrate that understanding the villager extraction decisions in a particular setting leads to better-informed buffer zone width and enrichment policy decisions.

\section{Discussion and conclusion}

Despite the widespread use of buffer zones in protected areas worldwide to enhance the positive, and reduce the negative, impact of conservation on local communities, and vice versa (Wild and Mutebi, 1996), few analyses inform the size and management of that buffer zone (Dixon and Sherman, 1990; Shafer, 1999; and Dudley, 2008). To fill that gap, we explore the impact of buffer zone width, in tandem with enforcement at the buffer-core boundary and with enrichment in the buffer zone, on villagers' extraction patterns. Expanding on previous analysis, this paper focuses on the impact of buffer zone policy on protecting core zone ecosystems from illegal extraction. The framework that we have developed demonstrates that buffer zones can improve returns to villagers and contribute to deterrence of illegal extraction in the core zone, but only at sizes large enough to change marginal extraction distance decisions.

Our model also demonstrates implicitly that buffer zone sizing decisions should reflect absolute widths/areas rather than focusing on some proportion of the forest. Information about the area in which a villager extracts in a no-enforcement setting - which can create a "natural core" of no extraction and no enforcement matters more for determining the appropriate buffer zone size and the related levels of enforcement of the core zone than the size of the forest itself (Robinson et al, 2002; 
Albers, 2010). Because absolute distances drive the extraction decisions, in similar ecological and socioeconomic settings, forest managers using our framework would locate proportionately smaller buffer zones in larger forests than in smaller forests. Although little systematic data describe the relative size of buffer zones in practice, Götmark et al. (2000) found buffer zones in Sweden of around 200 meters necessary, which accounted for up to 50 percent of the forest area. In contrast, in the large Amani nature reserve in Tanzania, managers established a proportionally smaller buffer zone. However, as this and earlier papers have shown, the optimal size of a buffer zone also depends on agro-ecological and socio-economic characteristics of the area and the population, which could differ between small and large forests.

Our results stem from analysis of a model of homogeneous extractors and homogeneous resources but consideration of previous analyses of related models suggests the impact of heterogeneity on patterns of degradation and buffer zone sizes within the framework of this model. First, the model presented here assumes that villagers extract a composite resource or just one specific resource and that that resource occurs homogeneously across space. If the resource occurs in particular locations or clusters across space, as in Robinson et al. (2008), this modelling approach's results still apply albeit with the modification that buffer zone width considers which clusters are within the buffer zone and within the core. If extractors collect a number of different resources, their returns to extraction may vary with the resource collected on that trip, implying different length trips for different resources collected, in which case the buffer zone/core boundary matters differently for each resource. In practice, a manager might choose that boundary location based on the resource that causes the most ecological damage to the core area or that provides lower returns to villagers, depending on their objective. 
Robinson et al. (2002) derives spatial extraction and forest degradation patterns for villagers who display heterogeneity in labour opportunity costs and finds that villagers with lower opportunity costs of labour, when unconstrained, extract over longer distances into the forest. Under these conditions, the pattern of resource degradation therefore reflects decreasing levels of extraction with distance further into the forest because only villagers with lower opportunity costs of labour extract further into the forest. Within the context of the model in this paper, with heterogeneous villagers the forest manager's decision over the optimal width of the buffer zone would take into account whether it is worth enforcing the boundary of a large buffer zone if only a few villagers are constrained by such a buffer zone. This decision would be influenced by, for example, whether the forest manager's objective is to minimize total biomass extracted from the forest or to maximize the total area of pristine forest. In the cases of heterogeneity in resource density across space, resource type, and extractors' opportunity costs of labour, the basic relationships between buffer zone size, villager decisions, and enforcement probabilities discussed in this paper remain but the heterogeneity implies a less clear cut buffer zone sizing decision because heterogeneity modifies the spatial pattern of resource degradation in ways that require consideration by a manager. Managers with different objective functions, such as one that considers only values from pristine core areas versus one that considers rural welfare, will make different buffer zone size and enforcement decisions both with and without heterogeneity (Robinson et al, 2011).

Our analysis considers one period's decisions and one threat - illegal extraction - to core zones of protected areas. A dynamic perspective would provide further input into buffer zone sizing and management decisions but would not overturn the central results here about the interactions between zone size, enforcement 
levels, and degraded resources in the buffer zone. Similarly, ecological determinants of buffer zone size and management might trump the extraction-degradation concerns emphasized here in some settings. Even in those situations, however, successful protection of core resources requires an understanding of how villagers respond to buffer zone management. In other situations, prioritization of rural development goals over conservation goals may lead to different buffer zone management decisions but, again, improving villager welfare requires understanding villager response to forest management policy.

Remote sensing imagery and site-surveys show patterns of relatively intense resource degradation in buffer zones as compared to within core zones of protected areas (Bruner et al., 2001; Lee et al., 2007). Still, the core zones of most parks show some degrading activity, which implies a significant role of illegal activities resulting from incomplete enforcement in those areas. Although analysts often depict the difference in resource quality in buffers and core zones, and between parks and surrounding areas, as evidence of core zone effectiveness, those differences represent the interaction of policies like buffer zone width and enforcement with villagers' extraction decisions. Patterns of resource quality cannot be understood without an understanding of the behavioural decisions that have generated that pattern. In this case, illegal extraction in the core diminishes the benefits of the core zone policy and represents something akin to leakage. Similarly, the intensive use of buffer zones and the resulting degraded resource there represents leakage of extraction activities from the core to the buffer zone.

Zoning of protected areas, and the management of those zones, is an inherently spatial management decision. In turn, the success of buffer zone 
management relies on the spatial response of villagers to those decisions. Although park zoning decisions often reflect spatial aspects of ecological processes, the spatial aspects of the economic decisions by villagers rarely inform zone designations and management despite their importance to the policy's success. 


\section{References}

Adhikari, B., Williams, F., and Lovett, J.C., 2007. Local benefits from community forests in the Middle Hills of Nepal," Forest Policy and Economics 9, 464-78.

Albers, H. J., 2010. Spatial modelling of extraction and enforcement in developing country protected areas. Resource and Energy Economics 32, 165-179.

Becker, G. S. 1968. Crime and Punishment: An Economic Approach. Journal of Political Economy 76,169-217.

Bruner, A. G., Gullison, R. E., Rice, R. E., and da Fonseca, G. A. B., 2001. Effectiveness of parks in protecting tropical biodiversity. Science 291, 125128.

CIFOR. 2011. Forests and non-timber forest products. CIFOR Fact Sheets. http://www.cifor.cgiar.org/publications/corporate/factSheet/NTFP.htm 2011.

DeFries, R., Hansen, A., Newton, A. C., and Hansen, M. C., 2005. Increasing isolation of protected areas in tropical forests over the past twenty years. Ecological Applications 15, 19-26.

Dudley, N. (Editor). 2008. Guidelines for Applying Protected Area Management Categories. Gland, Switzerland: IUCN.

Figueroa, F., and Sanchez-Cordero, V., 2008. Effectiveness of natural protected areas to prevent land use and land cover change in Mexico. Biodiversity Conservation 17, 3223-3240

Götmark, F., Söderlundh, H., \& Thorell, M. 2000. Buffer zones for forest reserves: opinions of land owners and conservation value of their forest around nature reserves in southern Sweden. Biodiversity and Conservation, 9(10), 1377-1390.

Hjortso, C. N., Straede, S., and Helles, F., 2006. Applying multi-criteria decisionmaking to protected areas and buffer zone management: A case study in the Royal Chitwan National Park, Nepal. Journal of Forest Economics 12, 91-108.

Kohlin, G. and Parks, P.J., 2001. Spatial variability and disincentives to harvest: deforestation and fuelwood collection in South Asia. Land Economics 77, 2062.

Lee, T. M., Sodhi ,N. S., Prawiradilaga, D. M., 2007. The importance of protected areas for the forest and endemic avifauna of Sulawesi (Indonesia). Ecological Applications 17, 1727-1741.

Lopez-Feldman, A. and J. E. Wilen. 2008. Poverty and spatial dimensions of nontimber forest extraction, Environment and Development Economics, 13(5): 621642

MacDonald, D.H., W. Adamowicz, and M. Luckert. 1998. A microeconomic analysis of choice of fuelwood collection sites in Zimbabwe; valuation through behavior and colaric expenditure. IN: World Congress of Environmental and Resource Economists. June. Venice. Pp. 25-27. 
Mahapatra, A.K., Albers, H.J., and Robinson, E.J.Z. 2005. The impact of NTFP sale on rural households' cash income in India's dry deciduous forest. Environmental Management 35, 258-65.

Martin, T. E. and Blackburn, G. A. 2009. The effectiveness of a Mesoamerican 'paper park' in conserving cloud forest avifauna. Biodiversity Conservation 18: 3841-3859.

Naughton-Treves, L., Holland, M. B., and Brandon, K., 2005. The role of protected areas in conserving biodiversity and sustaining local livelihoods. Annual Review of Environmental Resources 30, 219-252.

Persha, L. and Blomley, T., 2009. Management decentralization and Montane forest conditions in Tanzania, Conservation Biology 23, 1485-1496.

Robinson, E. J. Z., Williams, J.C., and Albers, H. J., 2002. The influence of markets and policy on spatial patterns of non-timber forest product extraction. Land Economics 78, 260-271.

Robinson, E. J. Z., Mahapatra, A. K., and Albers, H. J., 2010. Protecting poor countries' forests: Enforcement in theory and practice. Journal of Natural Resources Policy Research 2, 25-38.

Robinson, E. J. Z., Albers, H. J., and Williams, J. C., 2008. Spatial and temporal modelling of community non-timber forest extraction. Journal of Environmental Economics and Management 56, 234-245.

Robinson, E. J. Z. and Kajembe, G. C., 2009, Changing access to forest resources in Tanzania", EfD Discussion Paper 09-10, Environment for Development Initiative and Resources for the Future, Washington DC, April.

Robinson, E. J. Z., Albers, H.J., and Williams, J.C., 2011. Sizing reserves within a landscape: The roles of villagers' reactions and the ecological-socioeconomic setting. Land Economics 87, 233-249.

Shafer, C., 1999. US national park buffer zones: Historical, scientific, social, and legal aspects. Environmental Management 23, 49-73.

Skonhoft, A., and Solstad, J. T., 1996. Wildlife management, illegal hunting and conflicts. A bioeconomic analysis. Environment and Development Economics, $1,165-181$.

Straede, S. and Treue, T., 2006. Beyond buffer zone protection: A comparative study of park and buffer zone products' importance to villagers living inside Royal Chitwan National Park and to villagers living in its buffer zone. Journal of Environmental Management 78, 251-267.

UNESCO. Man and Biosphere. 2011. "FAQ: Biosphere Reserves?" http://www.unesco.org.uk/uploads/biopshere\%20reserves\%20faq.pdf. Accessed 4/2011.

Wells, M., and Brandon, K., with Hannah, L., 1992. People and Parks: Linking Protected Area Management with Local Communities." Washington, DC: World Bank/WWF/USAID.

Wild R.G. and Mutebi, J., 1996. Conservation Through Community Use of Plant Resources. UNESCO People and Plants Working paper, no. 5. 
Figure captions

Figure 1: Schematic of spatial elements of the model

Figure 2: Relationship between width of buffer zone and village decisions/returns

Figure 3: Minimum enforcement probability required to deter villager from entering the exclusion zone as a function of the width of the buffer zone

Figure 4: Impact of varying level of degradation in the buffer zone on enforcement required to stop all villagers entering the protected zone 


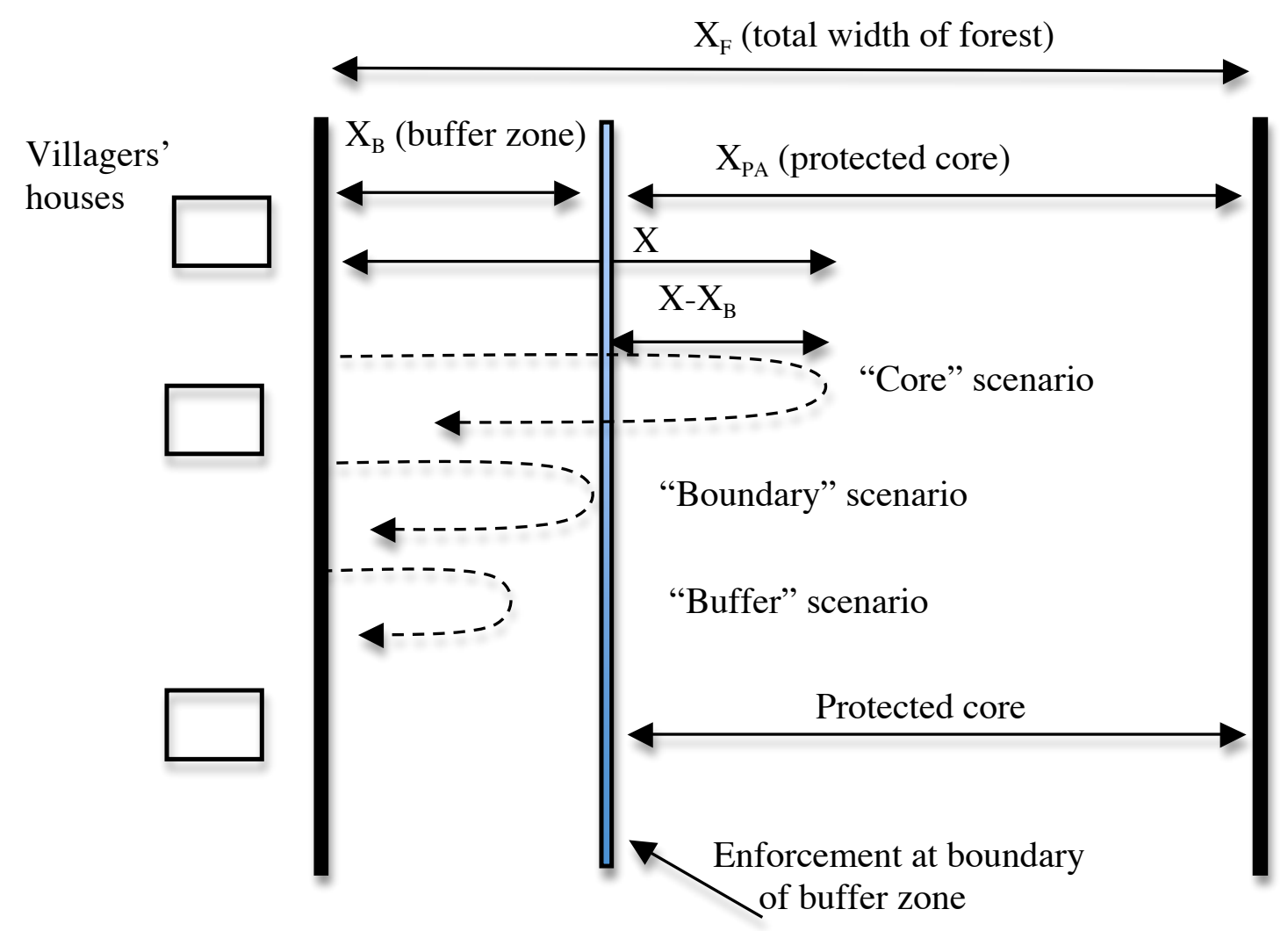

Figure 1. Schematic of spatial elements of the model 


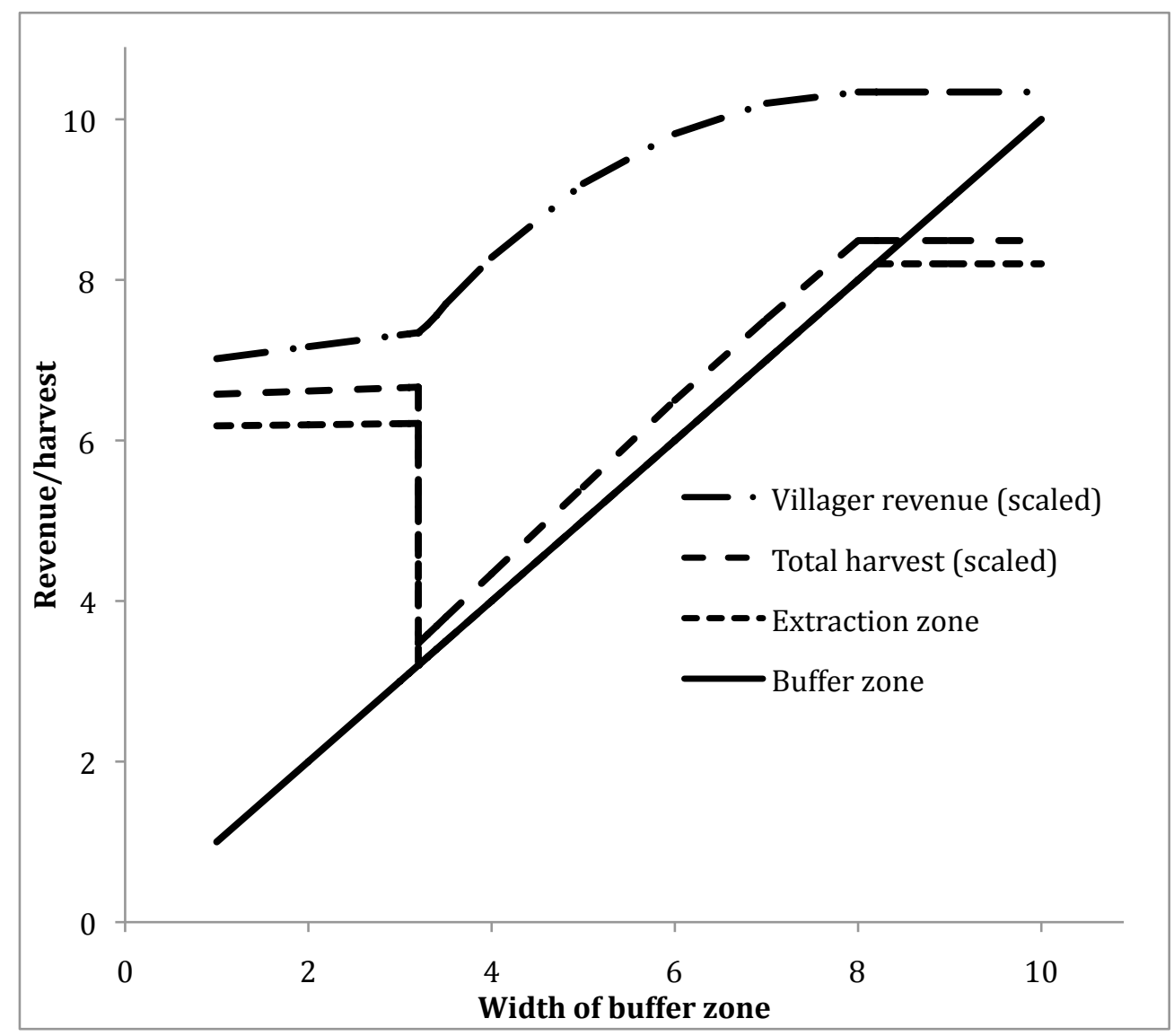

Figure 2: Relationship between width of buffer zone and villager decisions/returns 


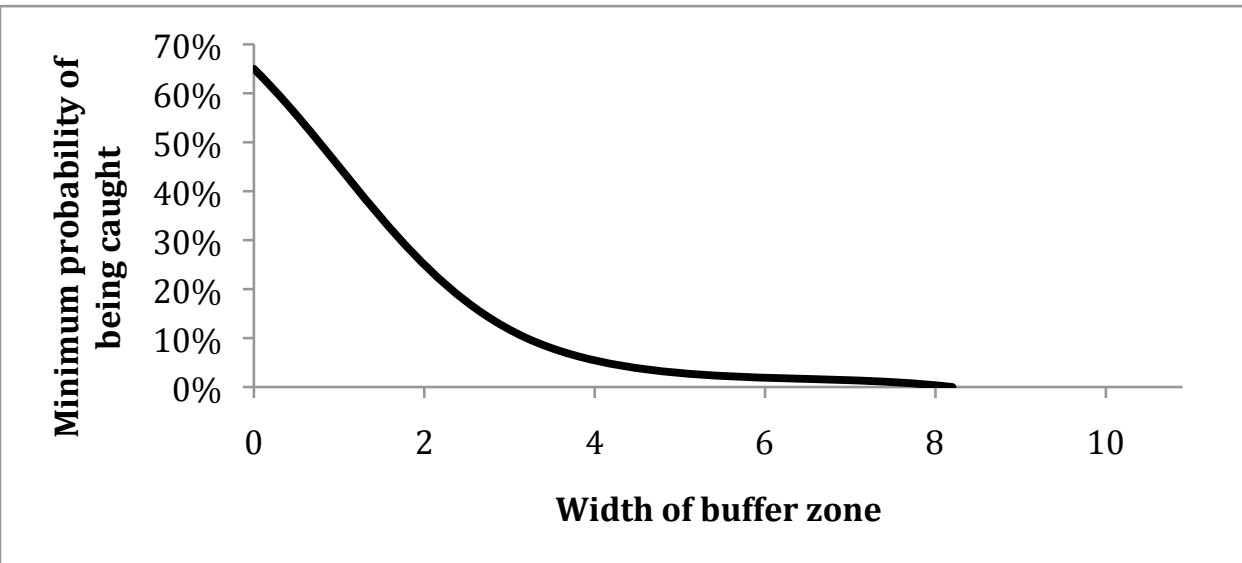

Figure 3: Minimum enforcement probability required to deter villager from entering the exclusion zone as a function of the width of the buffer zone 


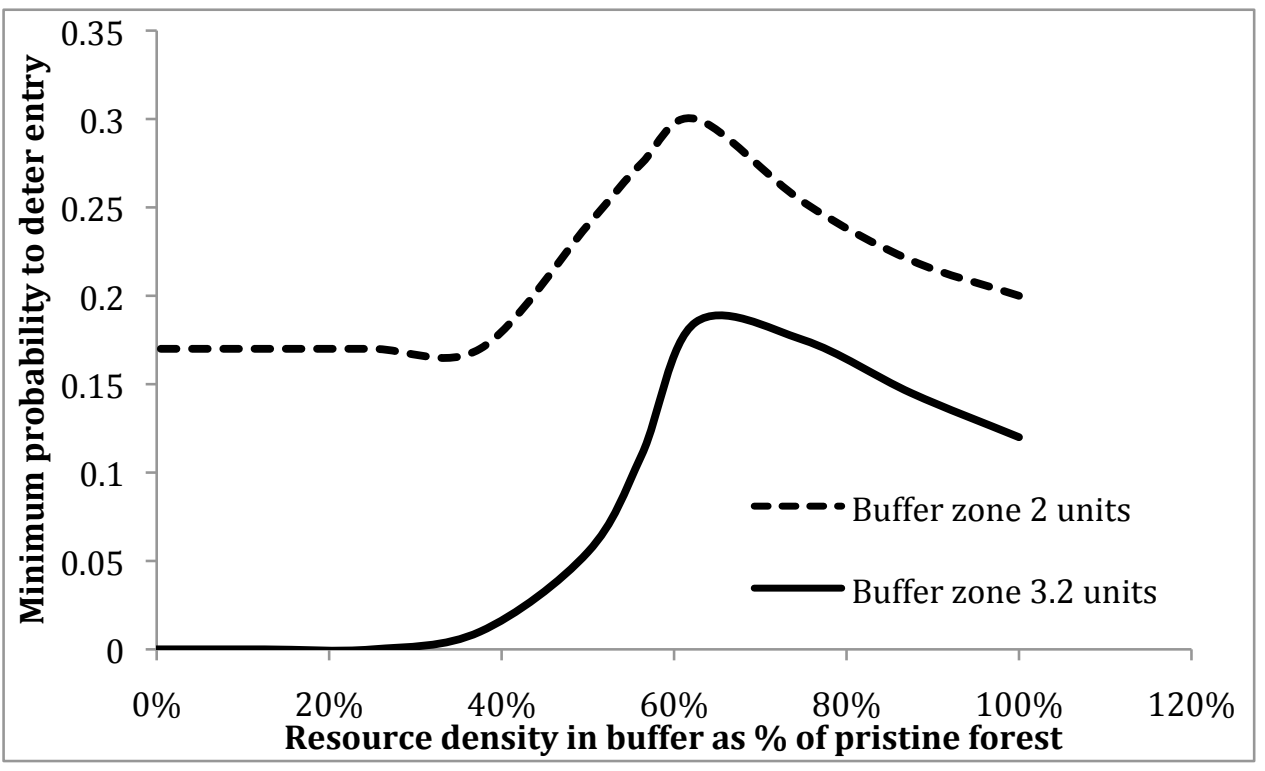

Figure 4: Impact of varying level of degradation in the buffer zone on enforcement required to stop all villagers entering the protected zone 